\title{
ANALISIS FAKTOR-FAKTOR YANG MEMPENGARUHI RANTAI PASOK DALAM PENINGKATAN DAYA SAING PRODUK KOPI DI KOTA PADANG
}

\author{
Analysis Factors of that Affect Supply Chain Effects in Improvement Competitiveness \\ Coffe Product at Padang City
}

\author{
Malikul Mulki Nasni", Rika Ampuh Hadiguna, Gunarif Taib \\ Pascasarjana Teknologi Industri Pertanian Universitas Andalas \\ *mulkimaliknasni@gmail.com
}

\begin{abstract}
Development of the small and medium scale ground coffee industry at Padang city shows that this business in the coffee industry provides prospects and opportunities, one of the ground coffee industry at Padang city is the Cap Tiga Sendok coffee powder, which has the smallest production that is equal to \pm 600 $\mathrm{kg} / \mathrm{month}$. It is necessary to analyze the factors that influence the supply chain in enhancement coffee products' competitiveness, using Structural Equation Modeling (SEM) with Partial Least Square (PLS). This study aims to analyze the factors that influence the supply chain in enhancement the competitiveness of coffee products at Padang city. From the results of the study, it was concluded that enhance the competitiveness of coffee products at Padang city, 3 variables out of 4 variables contained in the study were significantly affected, this factor is supply chain structure variable, government policy variables, and effectiveness and 1 variable had no significant effect on competitiveness namely supply chain channel variables, effort to increase the competitiveness of coffee products, requires support from the government to pay attention to aspects of supply chain channels in increasing the competitiveness of coffee products at Padang city.
\end{abstract}

Keywords : supply chain, coffee powder, competitiveness, SEM, enhancement

\begin{abstract}
ABSTRAK
Berkembangnya industri kopi bubuk berskala kecil dan menengah di Kota Padang menunjukkan bahwa usaha dibidang industri kopi ini memberikan prospek dan peluang, salah satu industri kopi bubuk yang ada di Kota Padang adalah kopi bubuk Cap Tiga Sendok yang memiliki kapasitas produksi terkecil yaitu sebesar $\pm 600 \mathrm{~kg} / \mathrm{bulan}$. Oleh karena itu, perlu dilakukan analisis faktor-faktor yang mempengaruhi rantai pasok dalam peningkatan daya saing produk kopi, untuk menghasilkan rumusan faktor-faktor tersebut dapat menggunakan Structural Equation Modeling (SEM) dengan bantuan Partial Least Square (PLS). Penelitian ini bertujuan untuk menganalisis faktor-faktor yang mempengaruhi rantai pasok
\end{abstract}


kopi dalam peningkatan daya saing produk kopi yang berada di Kota Padang, studi kasus pada usaha kopi cap Tiga Sendok. Variabel dan indikatornya diambil dari beberapa jurnal penelitian. Hasil penelitian disimpulkan bahwa dalam peningkatan daya saing produk kopi di Kota Padang dipengaruhi oleh 3 variabel dari 4 variabel yang terdapat pada penelitian secara signifikan yaitu variabel struktur rantai pasok, variabel efektifitas, dan variabel kebijakan pemerintah dan 1 variabel tidak berpengaruh secara signifikan terhadap daya saing yaitu variabel saluran rantai pasok, dalam upaya peningkatan daya saing produk kopi memerlukan dukungan yang lebih dari pemerintah untuk memperhatikan aspek saluran rantai pasok dalam peningkatan daya saing produk kopi di Kota Padang.

Kata Kunci : rantai pasok, kopi bubuk, daya saing, SEM, peningkatan

Submit: 18 Juni $2021 *$ Revisi: 25 Juni 2021 * Accepted: 3 Juli $2021 *$ Publish: 12 November 2021

\section{PENDAHULUAN}

Agroindustri merupakan subsistem agribisnis ketiga yang berperan sebagai industri berbasis sumber daya dan berpotensi dapat meningkatkan cadangan devisa serta penyediaan lapangan kerja Untuk itu pengembangan agroindustri juga merupakan salah satu opsi yang perlu dipertimbangkan [1].

Kebutuhan akan pangan nasional masih menumpukkan harapan pada sektor pertanian, termasuk subsektor perkebunan yang ikut menyumbang peranan yang berarti bagi pertanian di Indonesia, salah satunya adalah kopi. Kopi termasuk produk andalan bagi ekspor Indonesia. Data yang diperoleh dari Asosiasi Eksportir Kopi Indonesia (AEKI) bahwa volume ekspor kopi Indonesia rata-rata berkisar 350 ribu ton per tahun meliputi kopi robusta $(85 \%)$ dan arabika (15\%). Tujuan negara ekspor kopi indonesia terdiri lebih dari 50 negara diantaranya USA, Jepang, Italia, Jerman dan Inggris menjadi tujuan utama [2].
Proses pengolahan biji kopi menjadi kopi bubuk merupakan proses pengolahan kopi yang paling sederhana, biji kopi yang telah disangrai kemudian dihancurkan dan dikemas. Pembuatan kopi bubuk bisa dibagi ke dalam dua tahap yaitu tahap penyangraian dan tahap penggilingan. Industri pengolahan kopi pada umumnya menggunakan bahan baku biji kopi arabika dan robusta dengan komposisi perbandingan tertentu [3].

Industri kopi dalam negeri sangat beragam, dimulai dari unit industri berskala home industry hingga industri kopi berskala multinasional. Produkproduk yang dihasilkan tidak hanya untuk memenuhi kebutuhan konsumsi kopi dalam negeri, melainkan juga untuk mengisi pasar di luar negeri. Hal tersebut menunjukkan bahwa konsumsi kopi di dalam negeri merupakan pasar yang menarik bagi kalangan pengusaha yang masih memberikan prospek dan peluang sekaligus menunjukkan adanya kondisi yang kondusif dalam berinvestasi dibidang industri kopi [2]. 
Industri yang paling berpengaruh besar terhadap perkembangan ekonomi di Kota Padang dan berperan sebagai penyediaan lapangan usaha adalah industri pengolahan. Menurut [4], industri pengolahan hasil pertanian merupakan industri unggulan karena industri ini terus menunjukkan perkembangan dan mampu menyerap tenaga kerja. Salah satu industri pengolahan hasil pertanian adalah industri pengolahan kopi bubuk. Berkembangnya industri kopi bubuk berskala kecil dan menengah di Kota Padang menunjukkan bahwa usaha dibidang industri kopi ini memberikan prospek dan peluang. Berdasarkan data yang diperoleh dari [4] diketahui bahwa terdapat beberapa industri formal kopi bubuk di Kota Padang. Salah satu industri kopi bubuk yang ada di Kota Padang adalah kopi bubuk Cap Tiga Sendok.

Usaha kopi bubuk Cap Tiga Sendok saat dikelola oleh Bapak Halim dan Bapak Edi Halim sering mengalami penurunan penjualan. Menurut pemilik usaha kopi hal ini disebabkan oleh produk tidak dikemas dan tidak ditata dengan baik, pemasaran hanya di warung-warung kecil. Usaha kopi bubuk Cap Tiga Sendok memiliki kapasitas produksi terkecil diantara usaha industri yang lainnya, yaitu sebesar \pm 600 $\mathrm{kg} / \mathrm{bulan}$. Hal ini menunjukkan bahwa permintaan kopi bubuk Cap Tiga Sendok lebih rendah dibandingkan dengan usaha kopi lainnya. Usaha kopi bubuk Cap Tiga Sendok masih mengalami penurunan penjualan, penyebab penurunan volume penjualan kopi dikarenakan menurunnya daya beli konsumen, wilayah pemasaran yang kecil dan meningkatnya jumlah pesaing. Penelitian ini bertujuan untuk menganalisis faktor-faktor yang mempengaruhi rantai pasok kopi dalam peningkatan daya saing produk kopi yang berada di Kota Padang, studi kasus pada usaha kopi cap Tiga Sendok, menggunakan Structural Equation Modeling (SEM) dengan bantuan Partial Least Square (PLS Smart 3.0). Penelitian ini diharapkan bermanfaat bagi pelaku usaha kopi cap tiga sendok khususnya dan pelaku usaha kopi di Kota Padang pada umumnya. Pengetahuan akan faktor-faktor apa saja yang mempengaruhi rantai pasok dalam peningkatan daya saing produk kopi dapat dijadikan pedoman untuk pelaku usaha kopi bubuk. Selain itu, hasil penelitian ini diharapkan juga dapat bermanfaat bagi pemerintah dalam merumuskan kebijakan tentang UMKM. Penelitian ini juga diharapkan dapat bermanfaat sebagai referensi bagi penelitian-penelitian selanjutnya.

\section{METODOLOGI PENELITIAN}

Metode penelitian yang dipakai adalah deskriptif kuantitatif dengan alat analisis menggunakan Structural Equation Modeling (SEM) merupakan salah satu metode analisis multivariat dalam ilmu sosial. Analisis multivariat merupakan metode serempak [5]. SEM atau model persamaan struktural merupakan analisis multivariat yang digunakan untuk menganalisis hubungan antar variabel secara kompleks. Analisis data dengan mengunakan SEM berfungsi untuk menjelaskan secara menyeluruh hubungan antar variabel yang ada dalam penelitian. SEM digunakan untuk memeriksa dan membenarkan suatu model [6].

Tahapan riset dimulai dari analisis kuisioner pakar dan praktisi, melakukan penelitian ke lapangan selanjutnya melakukan analisis faktor-faktor yang mempengaruhi rantai pasok dalam 
peningkatan daya saing produk kopi di Kota Padang yang variabel dan indikatornya diambil dari literatur beberapa jurnal penelitian, kemudian data yang telah didapatkan di olah dengan menggunakan Structural Equation Modeling (SEM) dengan Partial Least Square (PLS Smart 3.0). Variabel dan Indikator yang digunakan dapat dilihat pada Tabel 1 .

Tabel 1. Variabel dan Indikator

\begin{tabular}{|c|c|c|c|c|}
\hline No & Variabel Laten & Variabel indikator & Simbol & Sumber \\
\hline \multirow{2}{*}{1} & \multirow{2}{*}{ Saluran Rantai Pasok } & Efisiensi & $\mathrm{X}_{1 \mathrm{a}}$ & \multirow{2}{*}{ [7] } \\
\hline & & Saluran Pasokan Petani & $\mathrm{X}_{1 \mathrm{~b}}$ & \\
\hline \multirow{3}{*}{2} & \multirow{3}{*}{ Struktur Rantai Pasok } & Volume Rantai Pasok & $\mathrm{X}_{2 \mathrm{a}}$ & \multirow{3}{*}{ [8] } \\
\hline & & Permintaan & $\mathrm{X}_{2 \mathrm{~b}}$ & \\
\hline & & Kebutuhan Pelanggan & $\mathrm{X}_{2 \mathrm{c}}$ & \\
\hline \multirow{3}{*}{3} & \multirow{3}{*}{ Efektivitas } & Lembaga Kredit & $\mathrm{X}_{3 \mathrm{a}}$ & \multirow{3}{*}{ [9] } \\
\hline & & Manajemen & $\mathrm{X}_{3 \mathrm{~b}}$ & \\
\hline & & Kerja Sama & $\mathrm{X}_{3 \mathrm{c}}$ & \\
\hline \multirow{3}{*}{4} & \multirow{3}{*}{ Kebijakan Pemerintah } & Perbankan & $\mathrm{X}_{4 \mathrm{a}}$ & \multirow{3}{*}{ [8] } \\
\hline & & Teknologi & $\mathrm{X}_{4 \mathrm{~b}}$ & \\
\hline & & Kemitraan & $\mathrm{X}_{4 \mathrm{c}}$ & \\
\hline \multirow{3}{*}{5} & \multirow{3}{*}{ Daya Saing } & Peningkatan Produktivitas & $\mathrm{Y}_{1 \mathrm{a}}$ & \multirow{3}{*}{ [8] } \\
\hline & & Peningkatan Output Produk & $\mathrm{Y}_{1 \mathrm{~b}}$ & \\
\hline & & Peningkatan Kemampuan Daya Beli & $\mathrm{Y}_{1 \mathrm{c}}$ & \\
\hline
\end{tabular}

HASIL DAN PEMBAHASAN

\section{Diagram Jalur}

Diagram jalur merupakan salah satu teknik untuk menggambarkan sebuah konsep yang dibangun dengan menggunakan beberapa indikator terukur. Diagram jalur dalam penelitian ini dilakukan terhadap 5 variabel laten. Masing-masing variabel laten memiliki indikator.

Pada penelitian, terdapat 5 variabel laten dan masing-masing variabel terdapat indikator yang menjelaskan variabel laten dan mengambarkan kondisi nyata penelitian, variabel dan indikator diperoleh dari literature review penelitian terdahulu. Variabel X1 (saluran rantai pasok) yang dimaksud dalam penelitian ini adalah rangkaian kegiatan koordinasi pengadaan produk, persediaan, dan pengiriman produk kopi kepada pelanggan yang dijelaskan oleh dua indikator yaitu efisiensi dan saluran pasokan petani. Variabel X2 (struktur rantai pasok) dalam penelitian ini di jelaskan oleh 3 indikator yaitu: volume rantai pasok, permintaan, kebutuhan pelanggan. Untuk variabel X3 (efektivitas) yang dijelaskan oleh indikator lembaga kredit, manajemen, kerja sama. Variabel X4 (kebijakan pemerintah) dijelaskan oleh indikator perbankan, teknologi, dan kemitraan, sedangkan untuk varibel Y (daya saing) juga dijelaskan oleh beberapa indikator yaitu: peningkatan produktivitas, peningkatan output, peningkatan kemampuan daya beli.

Setelah seluruh data dari variabel dan indikator diatas diperoleh dari responden, data diolah dengan evaluasi model penelitian, yaitu evaluasi model 
pengukuran (outer model) dan evaluasi model struktural (inner model), yang nantinya untuk melihat variabel-variabel $\mathrm{X}$ yang berpengaruh secara signifikan terhadap variabel Y.

Pada masing-masing variabel laten memiliki beberapa indikator yang berbentuk angka yang dapat dilihat pada Gambar 1. Angka yang terletak antara variabel dengan masing masing indikatornya merupakan factor loading yang menggambarkan koefisien jalur atau pengaruh antar variabel. Angka yang terletak di dalam lingkaran pada variabel laten merupakan nilai $R^{2}$ yang menggambarkan kontribusi masingmasing variabel independen terhadap variabel dependen.

\section{Analisis Model Pengukuran (Outer Model)}

Sebelum dilakukan pengujian hipotesis. perlu dilakukan pengujian kelayakan data dengan mengukur validitas dan reliabilitas variabel teramati. Menurut Hulland (2010) model pengukuran yang baik harus memenuhi tiga kriteria yaitu reliabilitas (reliability), validitas konvergen (convergent validity) dan validitas diskriminan (discriminant validity). Hasil uji validitas dan reliabilitas dijelaskan sebagai berikut:

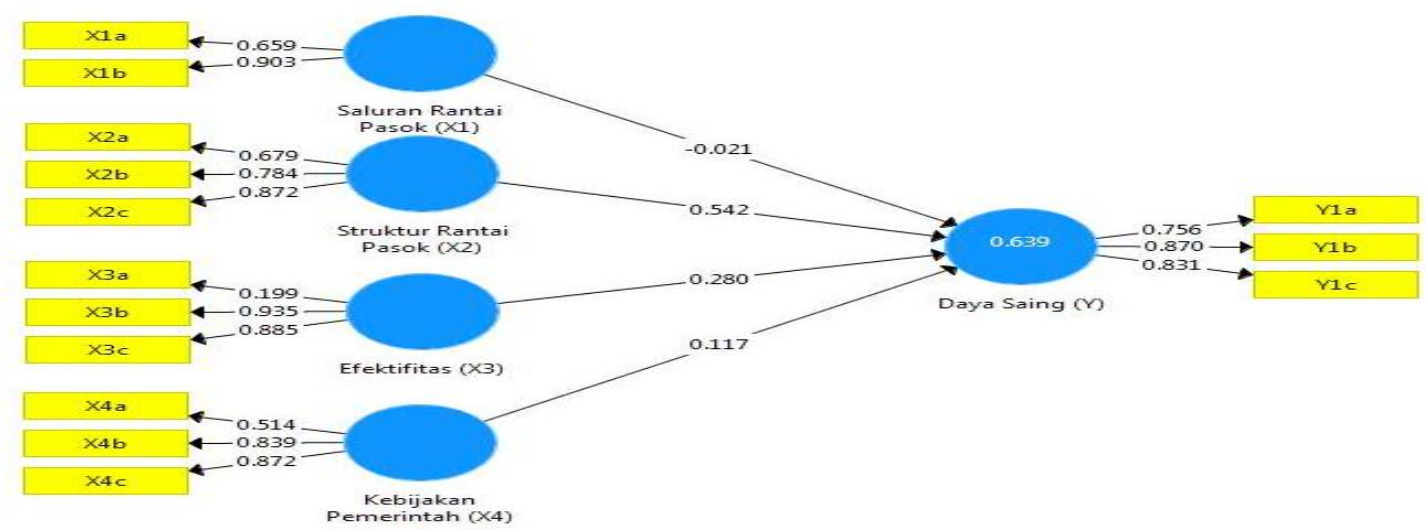

Gambar 1. Loading Faktor Model Penelitian (Pertama)

\section{a. Uji Validitas Konvergen}

Validitas konvergen ditunjukkan dengan korelasi antara indikator dengan variabel laten. Pembuktian validitas konvergen dapat dicapai dengan dua cara yaitu melalui pencapaian kriteria dan melalui uji perbandingan model. Pada penelitian ini validitas konvergen dibuktikan melalui pencapaian kriteria. Dalam pendekatan SEM/Smart PLS, sebuah pengukuran telah memenuhi validitas konvergen apabila telah memenuhi syarat yaitu memiliki loading faktor indikator minimal 0,5 [6]. Hasil analisis faktor tahap awal disajikan pada Gambar 1. Indikator yang mempunyai nilai loading faktor yang besar menunjukkan bahwa indikator tersebut memiliki hubungan yang kuat dengan variabel laten sehingga mendukung tingginya reliabilitas. Nilai loading faktor indikator yang direkomendasikan adalah 0,70 [10]. Nilai tersebut jika dikuadratkan akan menghasilkan reliabilitas sebesar 0,5. Nilai muatan faktor (factor loading) dipaparkan pada gambar 1 berada pada rentang nilai 
antara 0,199 sampai 0,935 artinya bahwa semua indikator belum mempunyai faktor loading lebih besar dari 0,5. Hasil ini menunjukkan bahwa semua indikator belum memiliki validitas konvergen yang baik. Dengan demikian, indikator belum dikatakan valid dalam mengukur masing-masing variabel latennya. Indikator dengan loading faktor kurang dari 0,50 yaitu $\mathrm{X} 3 \mathrm{a}$ indikator lembaga kredit pada variabel efektivitas didrop dari model penelitian. Hasil analisis faktor tahap 2 disajikan pada Gambar 2.

Nilai muatan faktor (factor loading) dipaparkan pada gambar 2 berada pada rentang nilai antara 0,513 sampai 0,936 artinya bahwa semua indikator mempunyai faktor loading lebih besar dari 0,5. Hasil ini menunjukkan bahwa semua indikator memiliki validitas konvergen yang baik. Dengan demikian, indikator dikatakan valid dalam mengukur masing-masing variabel latennya. b. Uji Validitas Diskriminan

Uji validitas diskriminan dilakukan untuk mengetahui seberapa jauh perbedaan nilai validitas suatu variabel bila dibandingkan dengan variabel lainnya. Salah satu cara untuk melakukan pengukuran validitas diskriminan adalah dengan membandingkan nilai akar kuadrat dari average variance extracted (AVE) yang diperoleh melalui nilai korelasi antar variabel [11]. Apabila nilai akar kuadrat average variance extracted (AVE) variabel laten lebih besar dari 0,7 dan lebih besar dari nilai korelasi dengan seluruh variabel laten lainnya maka dikatakan memiliki validitas diskriminan yang baik. Direkomendasikan nilai pengukuran AVE harus lebih besar dari 0,50. Hasil nilai AVE dan akar kuadrat AVE (fornell larcker criterion).

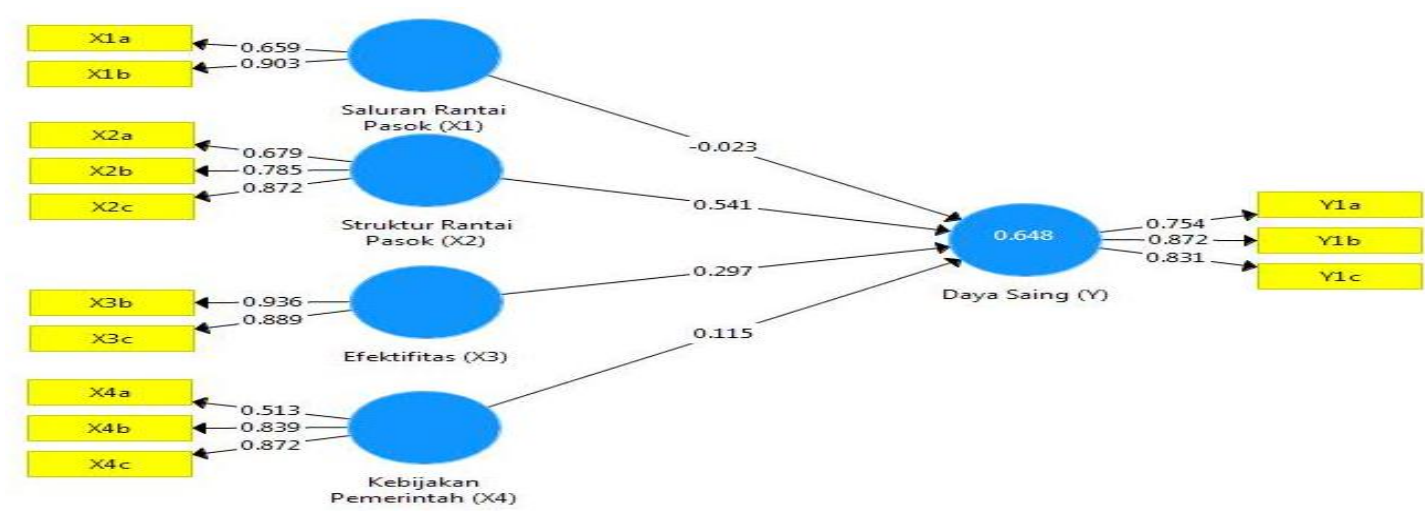

Gambar 2. Loading Faktor Model Penelitian (Kedua) 
Tabel 2. Nilai Akar Kuadrat AVE

\begin{tabular}{|c|c|c|c|c|c|}
\hline & $\begin{array}{c}\text { Daya } \\
\text { Saing }(Y)\end{array}$ & $\begin{array}{c}\text { Efektifitas } \\
\left(\mathbf{X}_{3}\right)\end{array}$ & $\begin{array}{c}\text { Kebijakan } \\
\text { Pemerintah } \\
\left(\mathbf{X}_{4}\right)\end{array}$ & $\begin{array}{c}\text { Saluran } \\
\text { Rantai } \\
\text { Pasok }\left(\mathbf{X}_{1}\right)\end{array}$ & $\begin{array}{c}\text { Struktur } \\
\text { Rantai } \\
\text { Pasok }\left(\mathbf{X}_{2}\right)\end{array}$ \\
\hline Daya Saing (Y) & 0.820 & & & & \\
\hline Efektifitas $\left(\mathbf{X}_{\mathbf{3}}\right)$ & 0.609 & 0.913 & & & \\
\hline $\begin{array}{l}\text { Kebijakan } \\
\text { Pemerintah }\left(\mathbf{X}_{4}\right)\end{array}$ & 0.645 & 0.590 & 0.759 & & \\
\hline $\begin{array}{l}\text { Saluran Rantai } \\
\text { Pasok }\left(X_{1}\right)\end{array}$ & 0.433 & 0.326 & 0.448 & 0.790 & \\
\hline $\begin{array}{l}\text { Struktur Rantai } \\
\operatorname{Pasok}\left(\mathrm{X}_{2}\right)\end{array}$ & 0.744 & 0.465 & 0.674 & 0.569 & 0.783 \\
\hline
\end{tabular}

Tabel 2 menunjukkan bahwa nilai akar kuadrat AVE dari keseluruhan variabel laten berkisar antara 0,759 sampai 0,913 artinya bahwa nilai akar kuadrat AVE seluruh variabel lebih besar dari 0,7. Nilai AVE seluruh variabel pada tabel 3 berkisar antara 0,576 sampai 0,834 , artinya bahwa nilai akar kuadrat AVE seluruh variabel lebih besar dari 0,5. Hasil tersebut menunjukkan bahwa seluruh variabel laten yang digunakan dalam penelitian ini telah mempunyai validitas diskriminan yang baik.

\section{c. Reliabilitas Komposit}

Reliabilitas komposit merupakan reabilitas untuk mengukur variabel laten [11]. Reliabilitas ini menggunakan koefisien reliabilitas untuk menjelaskan model pengukuran yang diuji. [12] menyatakan bahwa koefisien ini merupakan koefisien konsistensi internal yang mendekati nilai koefisien internal Cronbach. Koefisien reliabilitas ini cocok untuk pengukuran konjenerik yang mengansumsikan bahwa presisi dan skala ukur antar indikator memiliki perbedaan. Kelompok Indikator yang mengukur sebuah variabel memiliki reliabilitas komposit yang baik jika memiliki reliabilitas komposit $\geq 0,7$ meskipun bukan merupakan standar absolut. Hasil reliabilitas komposit dipaparkan pada Tabel 3.

Tabel 3 menunjukkan bahwa nilai reliabilitas komposit seluruh variabel laten berkisar antara 0,765 sampai dengan 0,909 artinya bahwa keseluruhan nilai reliabilitas komposit lebih besar dari 0,7. Hasil ini menunjukkan bahwa seluruh variabel laten mempunyai reliabilitas komposit yang baik.

\section{Analisis Model Struktural (Inner Model)}

Inner model merupakan model struktural untuk memprediksi hubungan kausalitas antar peubah variabel laten. Evaluasi inner model adalah untuk mengevaluasi pengaruh konstruk antar laten dan pengujian hipotesis. Model struktural dievaluasi dengan menggunakan $R$-Square untuk konstruk dependen, nilai koefisien path atau $t$ value tiap path untuk tingkat signifikansi dalam pengujian hipotesis. Semakin tinggi nilai $R$-Square berarti semakin baik model prediksi dari model penelitian yang diajukan [13]. Model struktural ini dievaluasi dengan $R$ Square untuk peubah endogen dan membandingkan t-hitung dengan t-tabel (t-tabel pada selang kepercayaan 95\% adalah 1.645). 
Tabel 3. Nilai AVE dan Reliabilitas Komposit

\begin{tabular}{|l|c|c|c|c|}
\hline & $\begin{array}{c}\text { Cronbach's } \\
\text { Alpha }\end{array}$ & rho_A & $\begin{array}{c}\text { Composite } \\
\text { Reliability }\end{array}$ & $\begin{array}{c}\text { Average Variance } \\
\text { Extracted (AVE) }\end{array}$ \\
\hline Daya Saing $(\mathbf{Y})$ & $\mathbf{0 . 7 5 8}$ & $\mathbf{0 . 7 8 4}$ & $\mathbf{0 . 8 6 0}$ & $\mathbf{0 . 6 7 3}$ \\
\hline Efektifitas $\left(\mathbf{X}_{3}\right)$ & $\mathbf{0 . 8 0 4}$ & $\mathbf{0 . 8 4 4}$ & $\mathbf{0 . 9 0 9}$ & $\mathbf{0 . 8 3 4}$ \\
\hline Kebijakan Pemerintah $\left(\mathbf{X}_{4}\right)$ & $\mathbf{0 . 6 2 8}$ & $\mathbf{0 . 7 1 1}$ & $\mathbf{0 . 7 9 5}$ & $\mathbf{0 . 5 7 6}$ \\
\hline Saluran Rantai Pasok $\left(\mathbf{X}_{\mathbf{1}}\right)$ & $\mathbf{0 . 4 2 8}$ & $\mathbf{0 . 5 1 1}$ & $\mathbf{0 . 7 6 5}$ & $\mathbf{0 . 6 2 5}$ \\
\hline Struktur Rantai Pasok $\left(\mathbf{X}_{2}\right)$ & $\mathbf{0 . 6 9 1}$ & $\mathbf{0 . 7 2 3}$ & $\mathbf{0 . 8 2 4}$ & $\mathbf{0 . 6 1 2}$ \\
\hline
\end{tabular}

Tabel 4. Nilai $R$ Square

\begin{tabular}{|l|r|r|}
\hline & \multicolumn{1}{|l|}{ R Square } & R Square Adjusted \\
\hline Daya Saing (Y) & 0.648 & 0.617 \\
\hline
\end{tabular}

a. Uji Kesesuaian Model (Goodness of fit)

Uji kesesuaian model berdasarkan kriteria yang ditetapkan yang dinamakan dengan Goodness of Fit. Goodness of Fit dari Inner Model diukur menggunakan $R$-square variabel laten dependen dengan interpretasi yang sama dengan regresi. Nilai $R^{2}$ dipaparkan pada Tabel 4.

Nilai $R$-square merupakan hasil (berupa persentase) atas representasi variabel independen terhadap variabel dependen. Nilai $R^{2}$ yang baik adalah diatas 0,2 (setara dengan 20\%). Berdasarkan nilai $R^{2}$ yang tertera pada Tabel 4 dapat dijelaskan bahwa variabel $\mathrm{Y}$ dapat dijelaskan oleh variabel $\mathrm{X} 1, \mathrm{X} 2$, X3 dan X4 sebesar $64,8 \%$, sisanya 35,2 $\%$ dijelaskan oleh variabel-variabel lainnya yang diteliti pada penelitian lain diluar penelitian ini.

\section{b. Uji Hipotesis Model Koefisien Jalur}

Uji hipotesis ini merupakan analisis kausalitas yang dilakukan untuk mengetahui hubungan antar variabel. Analisis kausalitas dapat digunakan untuk mengetahui pengaruh yang terjadi antara variabel eksogen dengan variabel endogen. Variabel eksogen dinyatakan berpengaruh secara signifikan terhadap variabel endogen jika nilai $p$ (probabilitas) $<0,05$. Hasil uji hipotesis dipaparkan pada Tabel 5.

Uji hipotesis dimaksudkan untuk menguji pengaruh sebuah variabel eksogen terhadap sebuah variabel endogen atau pengaruh sebuah variabel endogen terhadap variabel endogen lainnya. Dengan kata lain ingin menguji signifikansi pengaruh sebuah variabel yang mempengaruhi terhadap sebuah variabel lain yang dipengaruhi. Hipotesis dalam penelitian ini yaitu:

H0: variabel independen tidak berpengaruh signifikan terhadap variabel dependen

H1: variabel independen berpengaruh signifikan terhadap variabel dependen 
Tabel 5. Hasil Uji Hipotesis

\begin{tabular}{|c|c|c|c|c|c|}
\hline & $\begin{array}{l}\text { Original } \\
\text { Sample } \\
(\mathbf{O})\end{array}$ & $\begin{array}{l}\text { Sample } \\
\text { Mean } \\
\text { (M) }\end{array}$ & $\begin{array}{l}\text { Standard } \\
\text { Deviation } \\
\text { (STDEV) } \\
\end{array}$ & $\begin{array}{c}\text { T Statistics } \\
\text { (|O/STDEV|) }\end{array}$ & $\begin{array}{c}\mathbf{P} \\
\text { Values }\end{array}$ \\
\hline $\begin{array}{l}\text { Pengaruh Efektivitas }\left(\mathbf{X}_{3}\right) \\
\text { terhadap Daya Saing }(\mathbf{Y})\end{array}$ & 0.297 & 0.305 & 0.058 & 5.148 & 0.002 \\
\hline $\begin{array}{ll}\text { Pengaruh } & \text { Kebijakan } \\
\text { Pemerintah }\left(X_{4}\right) & \text { terhadap } \\
\text { Daya Saing }(Y) & \\
\end{array}$ & 0.115 & 0.113 & 0.036 & 3.179 & 0.012 \\
\hline $\begin{array}{llr}\text { Pengaruh } & \text { Saluran } & \text { Rantai } \\
\text { Pasok }\left(X_{1}\right) & \text { terhadap } & \text { Daya } \\
\text { Saing }(Y) & & \\
\end{array}$ & -0.023 & -0.008 & 0.109 & 0.210 & 0.421 \\
\hline $\begin{array}{lrr}\text { Pengaruh } & \text { Struktur } & \text { Rantai } \\
\text { Pasok }\left(X_{2}\right) & \text { terhadap } & \text { Daya } \\
\text { Saing }(Y) & & \\
\end{array}$ & 0.541 & 0.537 & 0.075 & 7.240 & 0.000 \\
\hline
\end{tabular}

Dasar pengambilan keputusan dari uji hipotesis tersebut yaitu jika nilai probalitasnya (nilai sig) $>0,05$ maka $\mathrm{H} 0$ ditolak dan jika nilai probalitasnya (nilai sig) < 0.05 maka H1 diterima. Hipotesishipotesis yang dapat diuraikan berdasarkan hasil yaitu: Berdasarkan tabel 5 untuk variabel saluran rantai pasok diperoleh nilai $\mathrm{P}$ values pengaruh saluran rantai pasok terhadap peningkatan daya saing produk kopi sebesar 0,421 lebih besar dari 0,05 berarti, saluran rantai pasok tidak berpengaruh signifikan terhadap daya saing produk kopi. Nilai Original Sample (O) yaitu sebesar -0,023 yang menunjukkan bahwa variabel saluran rantai pasok yang diukur dengan beberapa indikator (efisiensi dan saluran pasokan petani) memiliki hubungan negatif terhadap daya saing, hal ini dikarenakan efisiensi dan saluran pasokan petani yang meliputi kegiatan koordinasi pengadaan produk, persediaan, dan pengiriman produk kepada pelanggan bisa terpenuhi dan tidak mempengaruhi peningkatan daya saing produk kopi dengan nilai $\mathrm{T}$ statistik sebesar 0,210 lebih kecil dari $\mathrm{T}$ tabel 1,645. Berdasarkan uraian hubungan antar variabel diatas sehingga dengan demikian dapat disimpulkan hipotesis pertama ditolak atau dapat dikatakan bahwa saluran rantai pasok tidak berpengaruh signifikan terhadap daya saing.

Nilai $\mathrm{P}$ values pengaruh struktur rantai pasok terhadap peningkatan daya saing produk kopi sebesar 0,000 lebih kecil dari 0,05, berarti struktur rantai pasok berpengaruh signifikan terhadap peningkatan daya saing produk kopi. Nilai Original Sample (O) yaitu sebesar 0,541 yang menunjukkan bahwa dengan adanya struktur rantai pasok yang baik memiliki hubungan positif terhadap daya saing. Semakin baik struktur rantai pasok antar pelaku rantai pasok maka semakin besar juga pengaruhnya terhadap peningkatan daya saing produk kopi. Hal ini berarti variabel struktur rantai pasok yang diukur dengan beberapa indikator (volume rantai pasok, permintaan, dan kebutuhan pelanggan) berpengaruh signifikan dan memiliki hubungan positif terhadap peningkatan daya saing dengan nilai $\mathrm{T}$ statistik sebesar 7,240 lebih besar dari $\mathrm{T}$ tabel 1,645 sehingga dengan demikian dapat disimpulkan hipotesis kedua diterima atau dapat dikatakan bahwa struktur rantai pasok berpengaruh signifikan terhadap daya saing.

Nilai $\mathrm{P}$ values pengaruh efektivitas terhadap peningkatan daya saing produk kopi sebesar 0,002 lebih kecil dari 0,05, berarti efektivitas berpengaruh signifikan terhadap peningkatan daya saing produk kopi. Nilai Original Sample (O) yaitu 
sebesar 0,297 yang menunjukkan bahwa dengan adanya semangat efektivitas yang baik memiliki hubungan positif terhadap daya saing. Semakin baik pelaksanaan efektivitas dalam rantai pasok maka semakin besar juga pengaruhnya terhadap peningkatan daya saing produk kopi. Hal ini berarti variabel efektivitas yang diukur dengan beberapa indikator yang pada awal nya (lembaga kredit, manajemen, dan kerjasama) disederhanakan menjadi 2 indikator (manajemen, dan kerjasama) berpengaruh signifikan dan memiliki hubungan positif terhadap peningkatan daya saing dengan nilai $\mathrm{T}$ statistik sebesar 5,148 lebih besar dari $\mathrm{T}$ tabel 1,645 sehingga dengan demikian dapat disimpulkan hipotesis ketiga diterima atau dapat dikatakan bahwa efektivitas berpengaruh signifikan terhadap daya saing. Nilai P values pengaruh kebijakan pemerintah terhadap peningkatan daya saing produk kopi sebesar 0,012 lebih kecil dari 0,05, berarti kebijakan pemerintah berpengaruh signifikan terhadap peningkatan daya saing produk kopi. Nilai Original Sample (O) yaitu sebesar 0,115 yang menunjukkan bahwa dengan adanya kebijakan pemerintah yang tepat memiliki hubungan positif terhadap daya saing. Semakin baik pelaksanaan kebijakan pemerintah dalam rantai pasok maka semakin besar juga pengaruhnya terhadap peningkatan daya saing produk kopi. Hal ini berarti variabel kebijakan pemerintah yang diukur dengan beberapa indikator (perbankan, teknologi, dan kemitraan) berpengaruh signifikan dan memiliki hubungan positif terhadap peningkatan daya saing dengan nilai $\mathrm{T}$ statistik sebesar 3,179 lebih besar dari $\mathrm{T}$ tabel 1,645 sehingga dengan demikian dapat disimpulkan hipotesis keempat diterima atau dapat dikatakan bahwa kebijakan pemerintah berpengaruh signifikan terhadap daya saing.

Peningkatan daya saing produk kopi di kota Padang dipengaruhi oleh 3 variabel dari 4 variabel yang terdapat pada penelitian secara signifikan yaitu variabel struktur rantai pasok, variabel efektifitas, dan variabel kebijakan pemerintah dan 1 variabel tidak berpengaruh secara signifikan terhadap daya saing yaitu variabel saluran rantai pasok. Upaya peningkatan daya saing produk kopi memerlukan dukungan yang lebih dari pemerintah untuk memperhatikan aspek saluran rantai pasok dalam peningkatan daya saing produk kopi di Kota Padang. Perencanaan yang matang dalam proses produksi kopi sangat diperlukan dalam peningkatan produktivitas kopi di Kota Padang. Untuk meningkatkan daya saing kopi produsen kopi harus termotivasi untuk menggunakan teknologi baru untuk meningkatkan produksi, konsumen bisa saja merasa puas apabila produk yang mereka gunakan atau beli merupakan produk berkualitas. Serta dengan pelayanan yang baik merupakan kunci untuk mendapatkan pelanggan yang loyal dan pelayanan yang baik akan berdampak pada peningkatan kemampuan daya beli. Peningkatan kemampuan daya beli dapat dilakukan dengan kemudahan dalam mendapatkan produk hingga proses transaksi yang mudah. Komunikasi yang terjalin baik dengan konsumen akan mengakibatkan meningkatnya kemampuan daya beli konsumen akan produk. Upaya yang di kemukakan di atas untuk daya saing produk kopi di kota Padang selaras dengan penetapan upaya peningkatan daya saing. 


\section{KESIMPULAN DAN SARAN}

\section{Kesimpulan}

\section{Berdasarkan hasil penelitian analisis faktor-faktor yang} mempengaruhi rantai pasok dalam peningkatan daya saing produk kopi di Kota Padang (studi kasus Kopi cap Tiga Sendok), maka dapat disimpulkan bahwa:

1. Variabel saluran rantai pasok tidak berpengaruh signifikan terhadap daya saing produk kopi. Menunjukkan bahwa variabel saluran rantai pasok yang diukur dengan beberapa indikator (efisiensi dan saluran pasokan petani) memiliki hubungan negatif terhadap daya saing, hal ini dikarenakan efisiensi dan saluran pasokan petani yang meliputi kegiatan koordinasi pengadaan produk, persediaan, dan pengiriman produk kepada pelanggan bisa terpenuhi dan tidak mempengaruhi peningkatan daya saing produk kopi sehingga dengan demikian saluran rantai pasok tidak berpengaruh signifikan terhadap daya saing.

2. Variabel struktur rantai pasok berpengaruh signifikan terhadap peningkatan daya saing produk kopi dengan memiliki hubungan positif terhadap daya saing.

3. Variabel efektivitas berpengaruh signifikan terhadap peningkatan daya saing produk kopi, semakin baik pelaksanaan efektivitas dalam rantai pasok maka semakin besar juga pengaruhnya terhadap peningkatan daya saing produk kopi.

4. Variabel kebijakan pemerintah berpengaruh signifikan terhadap peningkatan daya saing produk kopi, dengan adanya kebijakan pemerintah yang tepat memiliki hubungan positif terhadap daya saing. Semakin baik pelaksanaan kebijakan pemerintah dalam rantai pasok maka semakin besar juga pengaruhnya terhadap peningkatan daya saing produk kopi.

\section{Saran}

Perlunya dukungan lebih dari pemerintah untuk memperhatikan aspek saluran rantai pasok dalam peningkatan daya saing produk kopi di Kota Padang. Perencanaan yang matang dalam proses produksi kopi sangat diperlukan dalam peningkatan produktivitas kopi di Kota Padang. Produsen kopi harus termotivasi untuk menggunakan teknologi baru untuk meningkatkan produksi, konsumen bisa saja merasa puas apabila produk yang mereka gunakan atau beli merupakan produk berkualitas, serta dengan pelayanan yang baik merupakan kunci untuk mendapatkan pelanggan yang loyal dan pelayanan yang baik akan berdampak pada peningkatan kemampuan daya beli. Peningkatan kemampuan daya beli dapat dilakukan dengan kemudahan dalam mendapatkan produk hingga proses transaksi yang mudah. Komunikasi yang terjalin baik dengan konsumen akan mengakibatkan meningkatnya kemampuan daya beli konsumen akan produk.

\section{DAFTAR PUSTAKA}

[1] Tambunan, T.T.H., Perekonomian Indonesia; Beberapa Masalah Penting. 2003, Jakarta: Ghalia Indonesia.

[2] Aeki-Aice. Asosiasi Eksportir dan Industri Kopi di Indonesia. 2015 30 Oktober 2015 [cited; Available from: aeki.aice.org. 
[3] Dept.Perindustrian, Road Map Industri Pengolahan Kopi. 2009, Direktorat Jenderal Agro dan Kimia: Jakarta.

[4] Disperindagtamben, Daftar Beberapa Industri Kecil di Kota Padang. 2011, Dinas Perindustrian, Perdagangan, Pertambangan dan Energi Kota Padang: Padang.

[5] Sholihin, M. and D. Ratmono, Analisis SEM-PLS dengan WarpPLS 3.0. 2013, Yogyakarta: Penerbit Andi.

[6] Hair, J.F., et al., Multivariate Data Analysis. 6th ed. 2006, Upper Saddle River, New Jersey: Pearson Education.

[7] Nahumury, M.A.I. and M.M.D. Widiastuti, Kajian Rantai Pasok Beras di Distrik Tanah Miring Kabupaten Merauke. Agricola: Jurnal Pertanian Universitas Musamus, 2015. 5(1).

[8] Purnomo, B.H., A.S. Rusdianto, and Y.W. Dewi, Formulasi Strategi Rantai Pasok Tepung Terigu untuk Industri Kecil Menengah di Kabupaten Jember. Jurnal Agroteknologi, 2014. 8(2): p. 140-152.

[9] Puryantoro. Strategi Peningkatan Daya Saing Mangga Manalagi dengan Pendekatan Supply Chain Management pada Perlakuan Rantai Pasok (Studi Kasus pada Pedangang Pengumpulan Mangga di Situbondo). in Seminar Nasional Hari Penelitian 2017. Universitas Kanjuruhan Malang: LPPM Unikama.

[10] Carmines, E.G. and R.A. Zeller, Reliability and Validity Assessment. 1979, New York: Sage Publications.

[11] Hair, J.F., et al., Multivariate Data Analysis. 7th ed. 2010, United States: Pearson Education.

[12] Hulland, J., M.J. Ryan, and R.K. Rayner, Modeling Customer Satisfaction: A Comparative Performance Evaluation of Covariance Structure Analysis Versus Partial Least Squares. Springer Handbooks of Computational Statistics, ed. C.W. Esposito Vinzi V., Henseler J., Wang H. 2010, Berlin, Heidelberg: Springer.

[13] Jogiyanto, Konsep \& Aplikasi PLS untuk Penelitian Empiris. 2011, Yogyakarta: BPFE. 